\title{
Institute to boost Japan sequencing efforts
}

Tokyo. Japan's first institute dedicated to the sequencing and analysis of DNA was officially opened last week. The Kazusa DNA Research Institute is unusual in that it is financed by the local prefectural government rather than the central government. Its large-scale sequencing facility will be open to outside users and visiting researchers from Japan and overseas.

The institute, located in a new science research park in the Chiba Prefecture east of Tokyo, cost $¥ 15$ billion (US\$150 million) to build and is equipped with a high-powered computer system linked into international and domestic computer networks. It has a large facility for DNA sequencing run by specially trained technicians.

Scientists at the institute, who are drawn from both universities and industry, will initially focus on two projects: the sequencing and analysis of the whole genome of a bluegreen algae (cyanobacterium) and the sequencing of large (more than $2 \mathrm{~kb}$ ) fulllength human cDNAs.

Plans for the institute were announced in early 1991 (see Nature 349,640; 1991), and the past three years have been spent training a team of 15 technicians to operate workstations and sequencers and to use computers to assemble sequences. There is a similar number of ordinary laboratory technicians, so the technical staff outnumber the current complement of 26 researchers.

According to Mitsuru Takanami, the president of the institute, the technicians had to be trained from scratch because such individuals are rare in Japan's public sector research system. Many more will be needed before the facility reaches full operational capability.

The institute has also had difficulty recruiting scientists. "Generally speaking, researchers in Japan like to hold more stable positions in national universities and com-

\section{Euro-lobby backs animal research}

Munich. More than 400 academic and industrial scientists are meeting in Strasbourg next week to inaugurate a new Europeanwide association to defend the use of laboratory animals in biomedical research.

The idea for the European Biomedical Research Association (EBRA) was first discussed at a meeting of the European Neuroscience Association in Madrid last year, in response to the activities of animal rights' groups. The founding members represent 25 European countries.

Ivar Aune, secretary of the Society for Health and Research - Germany's main research lobby group - points out that critics of the use of animals in research now wield considerable influence with the European Parliament. He argues that the benefits that animal experimentation bring to society, particularly in medicine, are often overlooked by such critics and their supporters.

EBRA will act as a representative voice for national research lobby groups. Ray Guillery, professor of human anatomy at the University of Oxford and chairman of the association's planning committee, says EBRA plans to educate the public, particularly schoolchildren, about the importance and necessity of animal research.

The group also aims to become an influential voice in legislation affecting animal research, particularly at the level of the European Union.

The association hopes to receive financing primarily through the corporate memberships of pharmaceutical companies and scientific societies, which will also provide a broad membership base.

Many research scientists, increasingly alarmed at the force of protests against ani- mal experiments, have welcomed the initiative. Norman Bowery, professor of neuropharmacology at London's School of Pharmacy, particularly applauds EBRA's aim of improving laboratory animal welfare in member countries with less stringent controls.

But not everyone is convinced of the need for another group to defend research. Sir Mark Richmond, for example, head of research and development for Glaxo, is worried about duplication of effort between national research lobbies and EBRA.

Richmond is reserving judgement on whether Glaxo, which is contributing to the costs of next week's meeting, should provide the association with more permanent support. "We will have to see how the situation evolves," he says.

Others, such as Dirk Bootma, a geneticist from the University of Rotterdam, argue that the strongest efforts to defend research should continue to take place at the national level. But national lobby groups are very enthusiastic about increasing European-level collaboration. Mark Matfield, head of the United Kingdom's Research Defence Society (RDS), and also a prominent member of EBRA's planning committee, says that the two most active national groups - the RDS and the German association - are working closely with the founding committee. The RDS, for example, will offer office space and services for the new body.

Priorities for the future direction and structure of EBRA will be decided at the inaugural meeting next week. High on the list is whether to establish a joint policy on primate research, an area heavily targeted by protesters.

Toni Feder

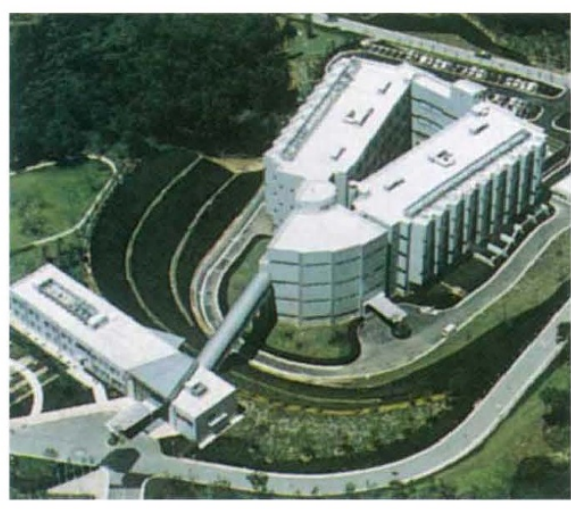

Mixed blessing: the Kasuza's countryside setting has drawbacks for house-hunters.

panies," says Takanami. Housing has posed a particular problem - it is not easy to buy a house in Japan and people are reluctant to move, particularly to the countryside.

A special floor in the institute has been set aside for joint research with public institutions and private companies. At present, it has several well-known "guest laboratory directors", including Michio Oishi, director of the Molecular Cellular Biology Laboratory of Tokyo University and Minoru Kanehisa of the Chemical Research Laboratory of Kyoto University who also heads Japan's Human Genome Centre, a genome database facility at Tokyo University (see Nature 361, 484; 1993).

The laboratory for sequencing the cyanobacterium genome plans to start by determining the whole genome sequence and then work on the structure and function of photosynthetic genes. This genome was chosen because of its manageable size (3.8 $\mathrm{Mb}$ ), and because of the group's interest in elucidating the photosynthetic system.

A second group is working on large fulllength human cDNAs. Takanami says such long cDNA is being neglected by human genome researchers around the world because short cDNA sequences are much easier to handle. So far, in preliminary work, the group has sequenced 100 such long fulllength $\mathrm{cDNAs}$ with a total length of $0.4 \mathrm{Mb}$.

Another aim of the facility is to develop DNA sequencing technology. Japan's attempts to develop efficient large-scale automatic sequencers have not so far been particularly successful. The Science and Technology Agency (STA) for several years funded a project to develop components of an automatic sequencing system in various companies.

But attempts to put the various machines together into one system at the Tsukuba Life Science Center of the Institute of Physical and Chemical Research have not been very successful and Japanese genome researchers still rely heavily on US sequencing technology. Takanami hopes his institute will alter this situation. 